\title{
In Response: Should Psychotherapy be Taught to Psychiatric Residents?
}

Robert Michels, MD

Cornell University Medical Center

Follow this and additional works at: https://jdc.jefferson.edu/jeffjpsychiatry

Part of the Psychiatry Commons

Let us know how access to this document benefits you

\section{Recommended Citation}

Michels, MD, Robert (1987) "In Response: Should Psychotherapy be Taught to Psychiatric Residents?," Jefferson Journal of Psychiatry. Vol. 5 : Iss. 2 , Article 16.

DOI: https://doi.org/10.29046/JJP.005.2.010

Available at: https://jdc.jefferson.edu/jeffjpsychiatry/vol5/iss2/16

This Article is brought to you for free and open access by the Jefferson Digital Commons. The Jefferson Digital Commons is a service of Thomas Jefferson University's Center for Teaching and Learning (CTL). The Commons is a showcase for Jefferson books and journals, peer-reviewed scholarly publications, unique historical collections from the University archives, and teaching tools. The Jefferson Digital Commons allows researchers and interested readers anywhere in the world to learn about and keep up to date with Jefferson scholarship. This article has been accepted for inclusion in Jefferson Journal of Psychiatry by an authorized administrator of the Jefferson Digital Commons. For more information, please contact: JeffersonDigitalCommons@jefferson.edu. 


\title{
In Response:
}

\section{Should Psychotherapy be Taught to Psychiatric Residents?}

\author{
Robert Michels, M.D.
}

The debate discussing whether psychotherapy should be taught to psychiatric residents (1) reflects the change, growth, and maturation of the profession. A theme that virtually defined psychiatric practice only a few decades ago is viewed by some as ready for discard while others still see it as essential. Of course, this isn't the first time. Eighty years ago some argued that the intellectual excitement and therapeutic promise of psychoanalysis was more than ample reason to discard the sterile and clinically nihilistic concern with constitutional neuropathic diatheses that marked 19th century psychiatry. Fortunately, wiser heads prevailed.

There are lively arguments today as to whether psychotherapy is scientific, effective, expensive, medical, socially appropriate, or ethical. I have views on each of these subjects, and more important I also have colleagues and friends who disagree with me on those views. However, for me the central issue in the teaching of psychotherapy to psychiatry residents is not the nature of psychotherapy, but rather the nature of psychiatric residencies. Residents should be interested in the newest and most exciting advances in their field, and also in the most pressing social problems that confront their profession. Residency training should encompass both of these, but residency education should encompass more. Residents should be trained to practice psychiatry, and for some residents today that practice will not involve the practice of psychotherapy. However, good residencies should also educate in the fundamentals of the profession and the fundamentals of its sciences. They should ensure that their graduates not only can practice today's psychiatry, but also can contribute to changing it, or at least can understand and participate in the psychiatry of the future. In order to do this, residencies must be wary of basing programs on current fashions in practice - whether psychoanalysis, insulin coma, lobotomy, ECT, community psychiatry, or psychopharmacology. They must preserve the fundamentals of

Dr. Michels is Barklie McKee Henry Professor and Chairman, Department of Psychiatry, Cornell University Medical College, and Psychiatrist-in-Chief at The New York Hospital. He is a member and former chairperson of the Committee on Therapy of the Group for the Advancement of Psychiatry. 
psychiatry that provide the potential for growth, development and change or, ironically, the misguided attempt to be more scientific will transform us from a science based profession to a trade.

I would agree with those who say that it is not necessary for contemporary residencies to train all residents to practice psychotherapy (although I think that it is a proud and exciting theme for those who select it). However, I would take strong exception with anyone who thinks that one can become a psychiatrist without being educated in psychotherapy. Good psychiatric education is reflected by knowledge, attitudes and skills, and requires experience doing psychotherapy as well as reading and studying the theories and findings of others, whether or not the resident will ever practice psychotherapy after graduation. Psychotherapy has a more central role in psychiatric residencies than in contemporary psychiatric practice, and its place in the curriculum reflects the general principle that educational programs should be more broadly based than the current preferred practices of the field.

I am not suggesting that psychotherapy is no longer an important part of contemporary psychiatry. I am simply noting that there are differences of opinion on this issue today, differences reflected in the debate. I am pointing out that whatever one's view concerning the appropriate role of psychotherapy in contemporary psychiatric practice, it has a vital place in psychiatric education. It provided a major context for many of the great discoveries of psychiatry in the past, is considered by most psychiatrists to be an important treatment in the present, and provides a vital setting for research and the development of new knowledge in the future. It is an essential and often unique laboratory for learning many aspects of psychopathology, the natural history of psychiatric disorders, and the nature of the caretaker relationship. We could probably train psychiatric therapist-technicians without exposing them to psychotherapy, just as we could train people to manage acid-base disturbances without teaching them biochemistry. These exercises would demonstrate that the component knowledge and skills required to be a physician can be dissected apart; but most would recognize that the product that results is thereby diminished $(2,3)$.

\section{REFERENCES}

1. Black DW, Ascher J, Cash H, et al: Should psychotherapy be taught to psychiatric residents? A debate. Jefferson Journal of Psychiatry 5(1):54-66, 1987

2. Michels R: Committee member. Teaching Psychotherapy in Contemporary Psychiatric Residency Training. Formulated by the GAP Committee on Therapy. Group for the Advancement of Psychiatry Report \#120. New York, Brunner/Mazel, 1987

3. Michels R: The place of psychoanalysis in psychiatric residency training, in The Role of Psychoanalysis in Psychiatric Education: Past, Present and Future. Edited by Weissman S, Thurnblad R. New York, International Universities Press, 1987 